\title{
Improving Reactivity and Selectivity of Aqueous-Based Heck Reactions by the Local Hydrophobicity of Phosphine Ligands
}

\author{
Gina M. Roberts, Shiyong Zhang, Yan Zhao,* L. Keith Woo* \\ Department of Chemistry, Iowa State University, Ames, Iowa 50011-3111 \\ email addresses of the corresponding authors: \\ zhaoy@iastate.edu, kwoo@iastate.edu
}

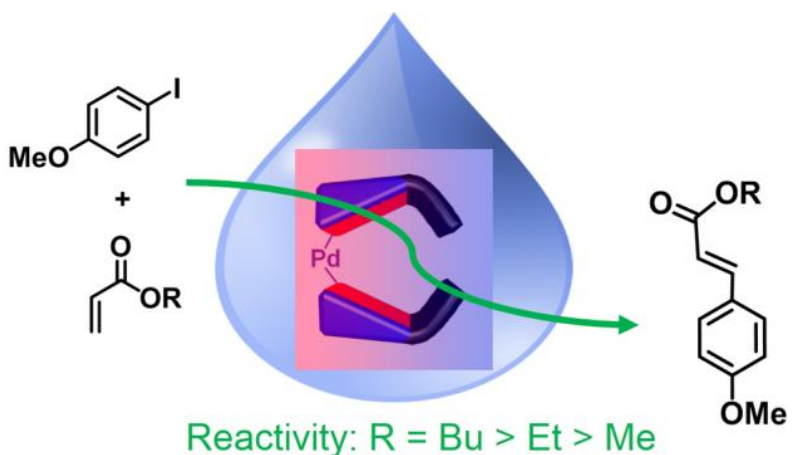

\begin{abstract}
$\underline{\text { Abstract }}$
Modification of a triarylphosphine with a cholate moiety affords a new ligand, $\mathbf{1}$, which is effective in palladium-catalyzed Heck cross-couplings between acrylates and aryl iodides under mild, aqueous reaction conditions. High yields, up to $99 \%$, wereachieved in water at $40{ }^{\circ} \mathrm{C}$. In competition studies, a more hydrophobic substrate ( $n$-Bu acrylate) was preferred over the least hydrophobic substrate (methyl acrylate), supportive of a localized hydrophobic microenvironment near the catalytic center. The enhanced reactivity and selectivity for hydrophobic substrates disappeared when the local hydrophobicity was eliminated using a standard water-soluble phosphine or in organic solvents.
\end{abstract}

Keywords: catalysis, selectivity, microenvironment, aqueous, hydrophobic effect 


\section{$\underline{\text { 1. Introduction }}$}

Transition metal-catalyzed reactions in water have attracted significant research attention. ${ }^{1,2}$ An important motivation comes from the low cost, abundance, nonflammability, and nontoxicity of water as a green solvent. If the reactants are organic and phase-separate from water, while the catalyst stays in the aqueous phase, the product can be easily separated. Traditionally, transition metal catalysts are made water-soluble by installing polar groups such as sulfonate on the metal-coordinating ligands. ${ }^{2,3,4}$ However, this method is limited to reactants with substantial solubility in water, since highly nonpolar substrates tend to have difficulty accessing catalysts located in the aqueous phase.

Because surfactant micelles can solubilize a wide variety of nonpolar compounds, chemists have also performed transition metal-catalyzed reactions in the micellar phase. ${ }^{5,6,7}$ The benefit of micelles is that they provide a local hydrophobic microenvironment to transition metal catalysts and may help enhance the local concentration of the substrate near the catalysts. Conversely, the surfactants may contaminate the products and could also hamper the product isolation by emulsion formation.

In this work, we report the synthesis of a cholate-functionalized phosphine ligand and its application in heterogeneous palladium-catalyzed Heck cross-coupling reactions. The facially amphiphilic cholate groupwas found to exert a stronginfluence on the activity and selectivity of the reactions, owing to its ability to create a hydrophobic microenvironment near the catalytic center.This feature resulted in a preference for hydrophobic substrates over less hydrophobicones by the catalyst. In contrast, the enhanced selectivity and reactivity was not observed in organic solvents or with a homogeneous control in which the catalystwas coordinated to water-soluble phosphines. 


\section{Results and Discussion}

\subsection{Ligand Synthesis}

The motivation for designing a cholate-functionalized phosphine ligand was derived from the unusual amphiphilicity and topology of cholic acid. Cholic acid and its associated bile salts (cholates) are formed in the liver and used as a surfactant for emulsifying lipids and cholesterol. ${ }^{8}$ Its rigid ring structure provides unusual facial amphiphilicity derived from the hydrophilic and hydrophobic moieties residing on opposite faces rather than in the conventional head-to-tail arrangement of amphiphiles such as sodium dodecyl sulfate (SDS). ${ }^{9}$ This unique structure and facial amphiphilicity has been exploited in supramolecular chemistry. ${ }^{9,10,11,12,13}$ According to Small's primary/secondary aggregation model, cholates form primary micelles at low concentrations in water, with 2-10 monomers in the structure stabilized mainly by hydrophobic interactions. ${ }^{14}$ As the cholate concentration increases, these primary micelles can aggregate to larger secondary structures through hydrogen bonds, leading to increased polydispersity in solution. ${ }^{6,15,16,17,18}$

Phosphine ligand 1 was readily derived from methyl cholate as shown in Scheme 1. Of the three hydroxyl groups, the most reactive hydroxyl resides at the C-3 position. ${ }^{19,20,21}$ Thus, the 3a-hydroxyl was selectively transformed into an azide by initially forming the $\beta$-mesylate (2) with methansulfonic acid under Mitsunobu conditions, and subsequently treating the mesylate with sodium azide. ${ }^{22}$ The overall stereochemistry of the $3 \alpha$-hydroxyl was retained in azide compound 3, thus maintaining the original bifacial topology of the cholate. Azide reduction to amine 4 was achieved with $\mathrm{PPh}_{3}$ in aqueous $\mathrm{THF}$, and the phosphine moiety was added via formation of an amide linkage between $\mathbf{4}$ and activated ester $\mathbf{5}$. The methyl ester functionality of 6 was hydrolyzed with $1.0 \mathrm{M} \mathrm{NaOH}$ in methanol $(\mathrm{MeOH})$. Isolation of the carboxylic acid (1) 
was achieved by purification on a silica gel column. Similar to cholic acid, $\mathbf{1}$ was essentially insoluble in water and sparingly to moderately soluble in ethanol, $\mathrm{MeOH}$, chloroform and dichloromethane. ${ }^{17,17}$ The ${ }^{31} \mathrm{P}$ NMR spectrum of $\mathbf{1}$ exhibited a single phosphine signal at $-5.0 \mathrm{ppm}$ with triphenylphosphate $(-18.0 \mathrm{ppm})^{23}$ as an external standard $\left(\mathrm{CDCl}_{3} / \mathrm{CD}_{3} \mathrm{OD}, 1: 1\right)$.
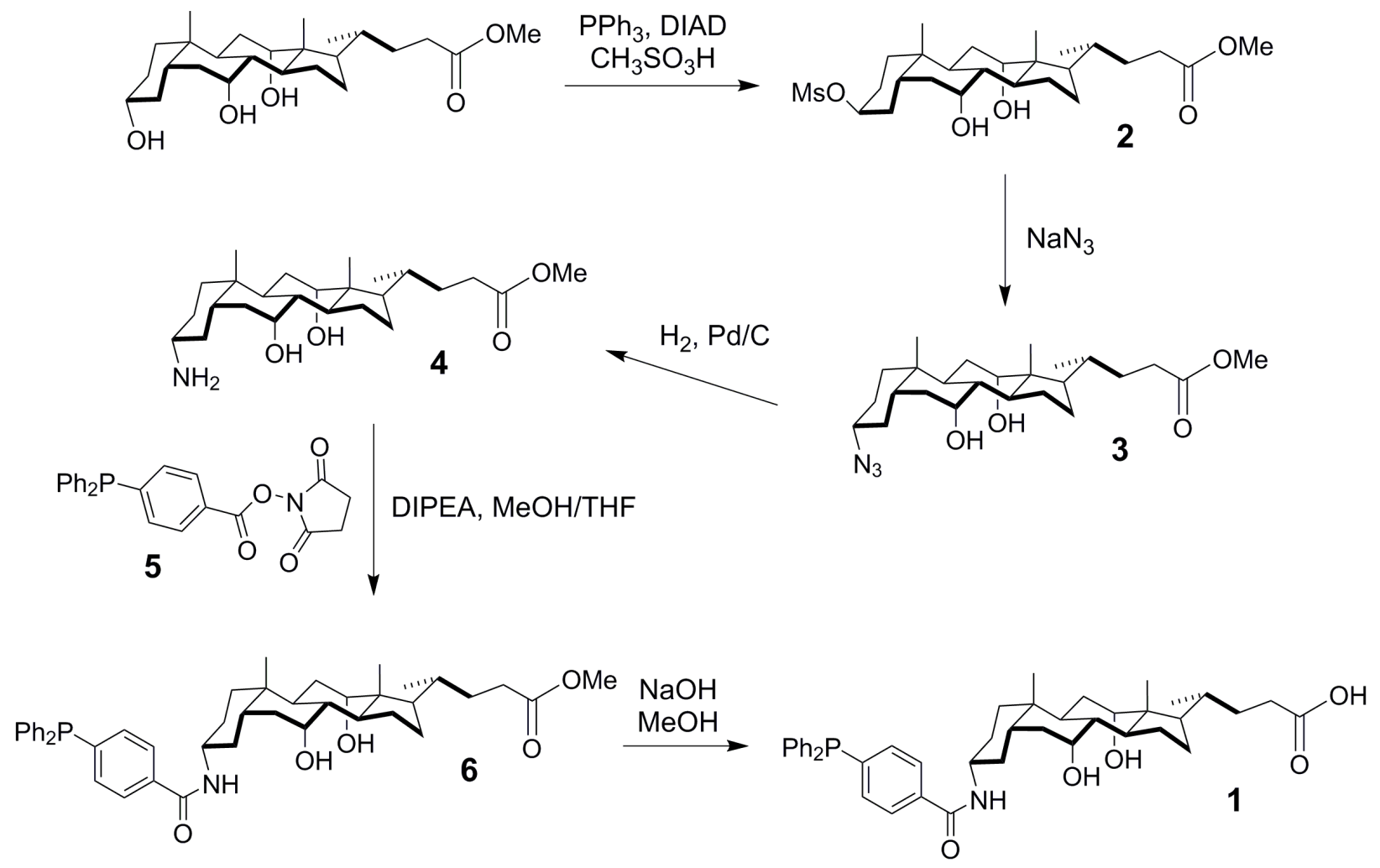

Scheme 1. Synthesis of phosphine ligand 1.

The insolubility of compound 1in water was not surprising. Even for cholic acid itself, the dominance of hydrophobic groups makes the molecule practically insoluble in water. Only when the carboxylic acid is deprotonated, the ionic carboxylate enables the molecule to selfassemble into micellar aggregates, which are soluble in water. ${ }^{18,24}$ For this reason, we employed a precatalyst complexation methodology for our catalysis. Sonication of $\operatorname{Pd}(\mathrm{OAc})_{2}$ and three equiv. of ligand 1 in $\mathrm{MeOH}$ produced a light yellow, hazy suspension within $30 \mathrm{~min}$ at ambient 
temperature. Removing $\mathrm{MeOH}$ under vacuo provided a solid yellow phosphinocholate $\mathrm{Pd}$ complex that was insoluble in water but formed an evenly dispersed suspension upon addition of $\mathrm{NEt}_{3}$. Increaseddispersion was likely due to deprotonation of the carboxylic acid moiety of $\mathbf{1}$, producing a charged Pd-L complex.

Studies by Jutand and coworkers established that a $\mathrm{Pd}^{0}$ complex was formed between $\mathrm{Pd}(\mathrm{OAc})_{2}$ and $\mathrm{PPh}_{3}$, and the dominate species was directly dependent on the amount of phosphine added to the system. ${ }^{25,26,27}$ Three equiv. of phosphine, in the presence of wet DMF, led to the overall formation of an anionic palladium(0) species (7) and phosphine oxide (eq. 1), identified by ${ }^{31} \mathrm{P}$ NMR.

$$
3 \mathrm{PPh}_{3}+\mathrm{Pd}(\mathrm{OAc})_{2}+\mathrm{H}_{2} \mathrm{O} \longrightarrow \mathrm{O}=\mathrm{PPh}_{3}+\left[\mathrm{Pd}\left(\mathrm{PPh}_{3}\right)_{2} \mathrm{OAc}\right]+\mathrm{AcOH}+\mathrm{H}^{+}
$$

Under a similar study with ligand $\mathbf{1}$ and $\mathrm{Pd}(\mathrm{OAc})_{2}$, analogous ${ }^{31} \mathrm{P}$ NMR peaks were observed. A solvent mixture of $1: 1 \quad \mathrm{CDCl}_{3}: \mathrm{CD}_{3} \mathrm{OD}$ sufficiently solubilized the yellow phosphinocholate $\mathrm{Pd}$ solid isolated from $\mathrm{MeOH}\left(1: 3, \mathrm{Pd}(\mathrm{OAc})_{2}\right.$ to 1), and three ${ }^{31} \mathrm{P}$ NMR signals were observed $(-5.0,16.9$, and $32.6 \mathrm{ppm})$. The signals at -5.0 and $32.6 \mathrm{ppm}$ corresponded to free and oxidized ligand $\mathbf{1}$, respectively. The peak at $16.9 \mathrm{ppm}$ was assigned to a $\mathrm{Pd}^{0}$ complex, $\mathbf{8}$, coordinated with two equiv. of $\mathbf{1}$. After $4 \mathrm{~h}$ in organic solvents, complex 8 mostly decomposed to palladium black, resulting in an increase in the phosphine oxide signal. Minor amounts of uncharacterized phosphine products were also detected, exhibitingbroad ${ }^{31} \mathrm{P}$ peaks around 30 ppm. ${ }^{1} \mathrm{H}$ NMR analysis revealed that both aryl and cholate backbone proton signals were broaderthan those of free ligand 1.If only two equiv. of $\mathbf{1}$ were used for Pd-complex formation, the isolated complex decomposed too rapidly for NMR analysis. Increasing the amount of phosphine to 4 equiv. of $\mathbf{1}$, provided similar results as those with 3 equiv., with the appearance of 
a transient broad peak around 5-7 ppm, which may correspond to higher coordinate palladium complexes, $\operatorname{Pd}(\mathrm{L})_{\mathrm{n}}(\mathrm{n}=3-4){ }^{26,28}$

Mass spectrometric analysis of the solid isolated from $\mathrm{MeOH}\left(\mathrm{Pd}(\mathrm{OAc})_{2} / \mathbf{1}=1: 3\right)$ supported the formation of a single bis-ligated palladium complex (8) with a mass cluster centered at $1498 \mathrm{~m} / \mathrm{z}$, and an isotopic mass pattern consistent with a $\mathrm{PdL}_{2}$ complex (see Fig. S18). A bound acetate ligand wasnot detected by MS analysis. In addition to the Pd-1complex (8), the mass spectrum exhibited a peak at $710 \mathrm{~m} / \mathrm{z}$, corresponding to a phosphine oxide species, indicating thatligand $\mathbf{1}$ was oxidized during formation of complex $\mathbf{8}$.

\subsection{Heterogeneous Heck Coupling Catalyzed by Pd-Phosphinocholate Complex 8}

The instability of the $\mathrm{Pd}$ complex in organic solvents (in the absence of suitable substrates) precluded its isolation. For the same reason, as described in the experimental section, the mixture obtained from $\mathrm{Pd}(\mathrm{OAc})_{2}$ and ligand $\mathbf{1}$ was used directly in the Heck coupling between aryl iodides and acrylates. As revealed in the ${ }^{31} \mathrm{P}$ NMR studies mentioned above, the mixture mainly consisted of complex $\mathbf{8}$, phosphine oxide, and excess ligand $\mathbf{1 .}$

Complex 8 was catalytically active at ambient temperature (Table 1, entry 1) and afforded the product in essentially quantitative yield under mild heating $\left(40{ }^{\circ} \mathrm{C}\right.$, entry 3$)$. Most importantly, the reaction gave the highest yield in water. Reactions in methanol (entries 5-7), a methanol/water mixture (entries 8-9), or acetonitrile (entry 10) afforded significantly less product, and higher temperature $\left(60^{\circ} \mathrm{C}\right)$ did not solve the problem.

Although many phosphine complexes tend to be air-sensitive, the activity of our catalyst was not significantly affected by the presence of oxygen. As a dry solid, the catalyst residue could be stored under light and air for more than 6 months with no substantial loss in activity (Table 1, entry 4). In water, the catalyst complex could be heated at $40{ }^{\circ} \mathrm{C}$ under atmospheric 
conditions for more than 3 days without any significant decomposition. ${ }^{29}$ It is possible that the extensive hydrophobic and hydrogen-bonding interactions in the aggregated form of the complex in water reduced the migration of $\mathrm{Pd}^{0}$, thus enhancing its stability. Note that, in organic solvents, the complex easily decomposed into palladium black.

Table 1. Optimization of Heck Coupling Reaction Conditions Using Complex 8 in Various Media. ${ }^{a}$<smiles>CCOC(=O)C=Cc1ccc(OC)cc1</smiles>

Rxn Solvent Amount of tert- Amount of $\quad t(h) \quad T\left({ }^{\circ} \mathrm{C}\right) \quad$ NMR butyl acrylate $\quad \mathrm{Et}_{3} \mathrm{~N}(\mathrm{mmol})$ Yield $(\%)^{\mathrm{b}}$

(mmol)

\begin{tabular}{llllllc}
\hline 1 & $\mathrm{H}_{2} \mathrm{O}$ & 0.12 & 0.18 & 4 & $\mathrm{RT}$ & 41 \\
2 & $\mathrm{H}_{2} \mathrm{O}$ & 0.12 & 0.18 & 4 & 40 & 78 \\
3 & $\mathrm{H}_{2} \mathrm{O}$ & 0.24 & 0.36 & 4 & 40 & 98 \\
$4^{\mathrm{c}}$ & $\mathrm{H}_{2} \mathrm{O}$ & 0.12 & 0.18 & 4 & 40 & 95 \\
$5^{\mathrm{d}}$ & $\mathrm{MeOH}$ & 0.12 & 0.18 & 5 & $\mathrm{RT}$ & trace \\
$6^{\mathrm{d}}$ & $\mathrm{MeOH}$ & 0.12 & 0.18 & 2 & 40 & 14 \\
$7^{\mathrm{d}}$ & $\mathrm{MeOH}$ & 0.12 & 0.18 & 2 & 60 & 14 \\
8 & $\mathrm{MeOH} / \mathrm{H}_{2} \mathrm{O}$ & 0.12 & 0.18 & 4 & $\mathrm{RT}$ & 24 \\
9 & $\mathrm{MeOH} / \mathrm{H}_{2} \mathrm{O}$ & 0.12 & 0.18 & 4 & 60 & 29 \\
10 & $\mathrm{CH} \mathrm{HN}^{2}$ & 0.12 & 0.18 & 2 & 40 & 48 \\
\hline
\end{tabular}

aConditions: See experimental for ligand-Pd precoordination method. bYields determined by NMR using mesitylene as internal standard. 'Catalyst was formed, dried and stored for 6 months before use in Heck coupling. d Precatalyst/MeOH solution used directly as reaction medium.

Despite the low solubility of complex $\mathbf{8}$ in any of the solvents, the best medium for the heterogeneous Heck catalysis was clearly water. The results suggest that the local hydrophobicity of the cholates was important to the catalysis. Most likely, the improved reactivity of $\mathrm{Pd}$-complex $\mathbf{8}$ derived from a microenvironment formed by the cholate ligands that 
enhanced the local concentrations of reactants around the active Pd center. It is also possible that the irregular shape and theamphiphilicity of the cholate, known to make cholate derivatives pack poorly in the solid state, ${ }^{30}$ enables similar hydrophobic channels or voids to be formed near the catalysts (vide infra).

Aqueous-based Heck couplingtypically gives higher yieldswith the use of inorganic bases. ${ }^{2,3,31}$ However in our cholate phosphine-Pd system, a substantial decrease in yield was seen when $\mathrm{NEt}_{3}$ was replaced with either $\mathrm{NaOAc}$ or $\mathrm{K}_{2} \mathrm{CO}_{3}$ (Table 2). Catalyst decomposition was extensive within $4 \mathrm{~h}$ with either of these inorganic bases. Conversely, if the alkyl groups of the amine were lengthened from ethyl to $n$-octyl, activity was strongly inhibited, but catalyst robustness was enhanced. For example, with $\mathrm{N}(\text { octyl })_{3}$, only a trace amount of product was detected for the coupling between 4-iosoanisole and tert-butyl acrylate, and no catalyst decomposition was visible after $24 \mathrm{~h}$ at $40{ }^{\circ} \mathrm{C}$ (entry 3).

Table 2. Effect of Base on Heck Coupling with Complex 8 in Aqueous Media. ${ }^{a}$

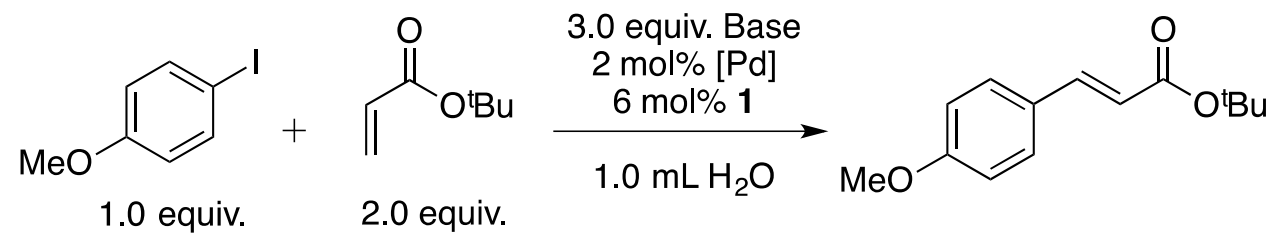

\begin{tabular}{llll} 
Rxn & Base & $\mathrm{t}(\mathrm{h})$ & ${\text { Yield }(\%)^{\mathrm{b}}}^{\mathrm{N}}$ \\
\hline 1 & $\mathrm{NaOAc}$ & 4 & 4 \\
2 & $\mathrm{~K}_{2} \mathrm{CO}_{3}$ & 4 & 21 \\
3 & $\mathrm{~N}_{\left(\mathrm{C}_{8} \mathrm{H}_{17}\right)_{3}}$ & 24 & Trace
\end{tabular}

${ }^{a}$ Conditions: See experimental for ligand-Pd precoordination method. $0.12 \mathrm{mmol}$ iodoanisole, $0.24 \mathrm{mmol}$ tert-butyl acrylate, $0.36 \mathrm{mmol}$ base, $2.4 \times 10^{-3} \mathrm{mmol} \mathrm{Pd}(\mathrm{OAc})_{2}, 7.5 \times 10^{-3} \mathrm{mmol} \mathrm{1}$, and $1 \mathrm{~mL} \mathrm{H}_{2} \mathrm{O}$. Stirred at $40{ }^{\circ} \mathrm{C}$. bAverage ${ }^{1} \mathrm{H}$ NMR yields for duplicate runs $( \pm 3)$. 
To understand the importance of the local hydrophobicity of the phosphinocholate ligand, we studied the Heck reactions of different acrylates with varying water solubility(Table 3). Since the alkyl group on the acrylate is three bonds away from the reactive center (the alkene), it is expected to have negligible electronic and steric effect on the Heck coupling.Meanwhile, as the alkyl substituent of an acrylate ester lengthens from methyl to hexyl, its solubility in water essentially decreases to zero. In agreement with our proposed local hydrophobicity-derived activity, more hydrophobic acrylates were clearly more reactive than less hydrophobic ones. For example, 2-ethylhexyl and n-butyl acrylates produced yields of 90 and $92 \%$, respectively, whereas methyl acrylate only afforded $12 \%$ yield.

Table 3. Effect of Acrylate Solubility on Heck Coupling with Complex 8 in Aqueous Media. ${ }^{a}$

\begin{tabular}{llccc} 
Rxn & R & Solubility $^{\mathrm{b}}(\mathrm{g} / \mathrm{L})$ & $\mathrm{t}(\mathrm{h})$ & ${\text { Yield }(\%)^{\mathrm{c}}}^{\mathrm{n}}$ \\
\hline 1 & $\mathrm{Me}$ & 60 & 4 & 12 \\
2 & $\mathrm{Et}$ & 15 & 4 & 77 \\
3 & $n-\mathrm{Bu}$ & 1.4 & 4 & 92 \\
4 & 2-ethylhexyl & $-{ }^{\mathrm{d}}$ & 4 & 90
\end{tabular}

${ }^{\mathrm{a} C o n d i t i o n s: ~ S e e ~ e x p e r i m e n t a l ~ f o r ~ l i g a n d-P d ~ p r e c o o r d i n a t i o n ~ m e t h o d . ~}{ }^{\mathrm{b}}$ Solubility of acrylate in water. ${ }^{\mathrm{c} A v e r a g e}{ }^{1} \mathrm{H}$ NMR yields for duplicate runs $( \pm 3) .{ }^{\text {d }}$ Solubility in water was negligible.

Importantly, the selectivity for hydrophobic acrylates was completely absent in organic solvent (DMF) in our competition studies. The catalytic complex was slightly more soluble in DMF than water, but was still predominantly a suspension. When methyl acrylate and $n$-butyl acrylate were used in a competition reaction to couple with 4-iodoanisole, a product ratio of 1:1 
was obtained in DMF (Scheme 2). In an analogous study with water as the solvent, the product ratio favored the $n$-butyl cinnamate product over the methyl analog (2.6:1), confirming the importance of hydrophobic interactions to the reactivity and selectivity.

\section{Scheme 2}

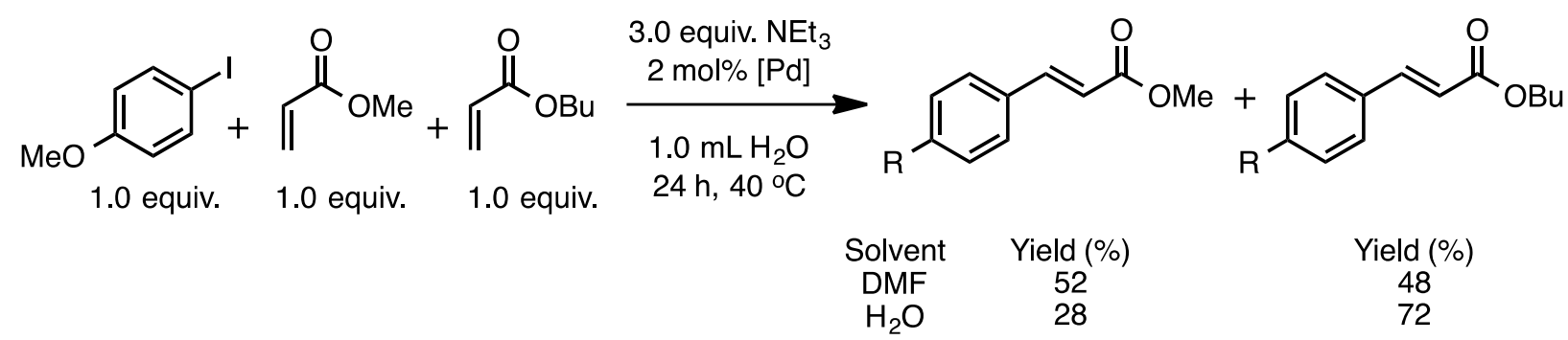

Although the catalytic system appeared heterogeneous, it was possible that the active palladium species during the reaction was water-soluble. To determine the phase of the active species, a heterogeneity test was performed with a reaction that was centrifuged after $2 \mathrm{~h}$ at 40 ${ }^{\circ} \mathrm{C}$. The solid and supernatant fractions were separated, and a second aliquot of reagents was added to each. Water was also added to the solid fraction. After an additional $2 \mathrm{~h}$ at $40{ }^{\circ} \mathrm{C}$, only the solid fraction proved to remain catalytically active, resulting in a total yield of $94 \%$. No additional product was detected by NMR analysis of the supernatant fraction, even after heating at $40{ }^{\circ} \mathrm{C}$ for an additional $6 \mathrm{~h}$.

Lack of reactivity with the supernatant fraction indicated that no active palladium species were dissolved in the aqueous layer. However, we were also interested in the distribution of $\mathbf{1}$ between the solid and supernatant fractions. In an additional separation study, a catalytic reaction was removed from heat after $2 \mathrm{~h}$ and the solid and solution phases were separated by centrifugation. Both fractions were thoroughly dried in vacuo. Upon dissolving each of the residues in $1: 1 \mathrm{CDCl}_{3}: \mathrm{CD}_{3} \mathrm{OD},{ }^{31} \mathrm{P} \mathrm{NMR}$ analysis indicated that all the phosphorous containing 
material remained in the original solid fraction. No detectable amount of cholate species was present in the aqueous solution fraction.

The conventional method in performing transition metal-catalyzed reactions in water is to install water-solubilizing groups such as sulfonate on the metal-coordinating ligands. ${ }^{2-4}$ Our results so far suggest that the presence of local hydrophobicity near the catalyst seems to be more important than water-solubility, at least in this particular system. To further verify the importance of the local hydrophobicity, we performed similar aqueous Heck coupling using a water-soluble phosphine ligand, sodium 4-(diphenylphosphino)benzoate (9), for its similar electronic property of the phosphine.

Consistent with our hypothesis, the reactions catalyzed by the Pd-9complex (Table 4) gave much poorer results than those catalyzed by the corresponding phosphinocholate complex (Table 1). In addition to yields never exceeding $30 \%$ with the water-soluble catalytic system, the selectivity for hydrophobic substrates was completely absent (Table 4, entries 1-5). The yields showed no improvements when the base or reaction solvent was varied. These resultsprovide addition support for the importance of local hydrophobicity for the catalysis. Although fully soluble in water and containing phenyl groups on the ligand, the Pd complex with ligand9 apparently did not possess the necessary local hydrophobic environmental as in the cholate-based catalyst $\mathbf{8}$ for the efficient Heck coupling between hydrophobic substrates.It should be mentioned that, with the proper ligands, excellent yields have been obtained in the literature for Pd-catalyzed Heck reactions in aqueous/organic solvents, even for less reactive substrates such as aryl bromides. ${ }^{32,33,34}$ This latter approach, however, is not expected to afford selectivity such as butyl over methyl acrylate demonstrated by our system. 
The scope of the catalyst's reactivity is exhibited in Table 5. In general, no (Z)-isomers were detected by ${ }^{1} \mathrm{H}$ NMR. For example the olefinic coupling constant for the trans protons was 16.0 Hz in the products. The catalyst was not active for aryl bromides or aryl chlorides. Both electron donating and electron withdrawing substituents on both the aryl and olefinic reagents produced good to excellent yields at $40{ }^{\circ} \mathrm{C}$.

Table 4. Results of Heck Coupling Reaction Conditions Using Water Soluble Ligand, 9,in Various Media. $^{\text {a }}$

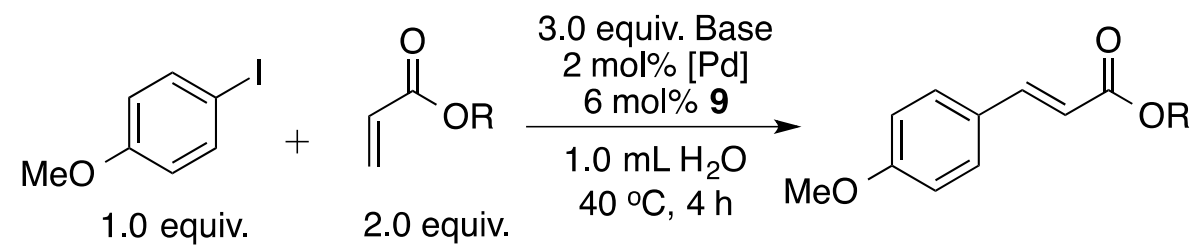


Table 5.Scope of Heck Cross-Coupling Reactions Catalyzed by 8 in Aqueous Media.<smiles>[R]C=Cc1ccc([R])cc1</smiles>

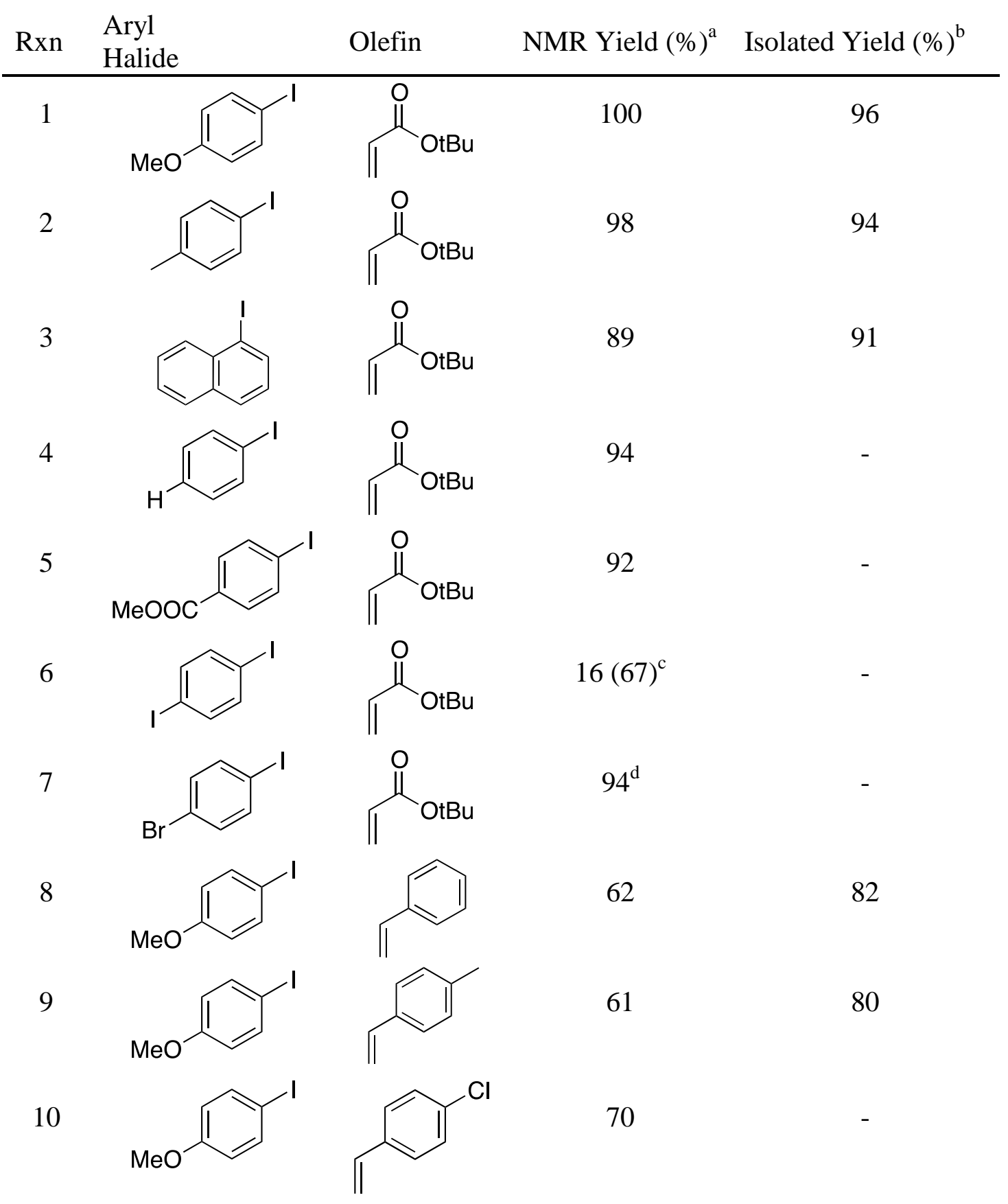


<smiles>Brc1ccccc1</smiles><smiles>C=CC(=O)OCCC</smiles>

12<smiles>Cc1ccc(Br)cc1</smiles><smiles>C=CC(=O)OCCC</smiles>

${ }^{a}$ Conditions: See experimental for ligand-Pd precoordination method.Average ${ }^{1} \mathrm{H}$ NMR yields for duplicate runs $( \pm 3)$. ${ }^{b}$ Isolated yield using scaled-up procedure. ${ }^{c}$ Parenthetical yield is of doubly coupled product. ${ }^{d}$ No doubly coupled product detected.

\section{Conclusions}

In comparison to the water-soluble $\mathrm{Pd}-\mathbf{9}$ complex, the $\mathrm{Pd}-$ phosphinocholate complex (8)afforded dramatically improved results in aqueous-based Heck coupling reactions. Although the catalytic activity was not high for aryl bromides or chlorides, the local hydrophobicity of the phosphinocholate ligand enabled quantitative yields for aryl iodides in cases while the watersoluble $\mathrm{Pd}-\mathbf{9}$ complex only afforded $<30 \%$ yields. In the literature, local hydrophobicity has been found to be important in other systems. ${ }^{35}$ Cyclodextrin has been used to improve Pdcatalyzed Heck reactions in aqueous/organic mixtures. ${ }^{36}$ In our case, despite the heterogeneity of the reaction system, the local hydrophobicity with the phosphinocholate enabled unusual selectivity among acrylates that was otherwise absent in organic solvents.

Although these results were obtained with an "easy" reaction (Heck coupling between aryl iodides and acrylates), the significance of the work lies in its implication in catalyst design. Heterogeneous catalysts are frequently prepared on a hydrophobic support such as activated carbon or graphene. Such catalysts, however, are "globally" hydrophobic and do not possess the localized feature exemplified by the phosphinocholate ligand. This work suggests that creation of a local hydrophobic microenvironment near the catalytic center can improve both the reactivity and selectivity of the catalyst. Since the hydrophobicity-derived reactivity and selectivity did not 
originate from the Pd metal or the catalytic reaction itself, we expect the principle could be applied to other systems as well.

\section{Experimental Section}

\subsection{General Method}

All reagents and solvents were ACS-certified grade or higher, and were used as received from commercial suppliers, unless otherwise indicated. The aqueous reactions used deionized water without further purification or degassing. Routine ${ }^{1} \mathrm{H},{ }^{31} \mathrm{P}$ and ${ }^{13} \mathrm{C}$ NMR spectra were recorded on a Varian VXR-400 spectrometer. Mass spectrometry for compounds 1 and $\mathbf{6}$ were performed on a Waters GCT GC-MS, using ESI as the ionization method. Mass spectrometry for complex 8 was performed on an Agilent 6540 Q-TOF LC-MS, using APCI as the ionization method. Centrifugation was performed with a Fisher Scientific Micro 17R Microcentrifuge. Syntheses of cholate derivatives 2-4 were accomplished as previously reported. ${ }^{37}$

\subsection{Syntheses}

4.2.1. Synthesis of compound 5: A mixture of 4-(diphenylphosphino)benzoic acid ( $153 \mathrm{mg}, 0.50$ mmol), N-hydroxysuccinimide (87 mg, $0.75 \mathrm{mmol}$ ), and 1,3-dicyclohexylcarbodiimide (DCC, $155 \mathrm{mg}, 0.75 \mathrm{mmol}$ ) was dissolved in $4.0 \mathrm{~mL}$ of anhydrous $\mathrm{CH}_{3} \mathrm{CN} / \mathrm{THF}(3: 1)$. The mixture was stirred at room temperature for $\sim 12 \mathrm{~h}$. The urea was separated by filtration and the filtrate evaporated to dryness leaving the active ester 5 as a light yellow powder $(203.3 \mathrm{mg}, 0.50 \mathrm{mmol}$, $100 \%$ ), which was used in the next step without further purification.

4.2.2. Synthesis of compound 6: Compound 5 ( $202 \mathrm{mg}, 0.50 \mathrm{mmol})$, diisopropylethylamine (DIPEA, $350 \mu \mathrm{L}, 2.0 \mathrm{mmol})$, and $4(253 \mathrm{mg}, 0.60 \mathrm{mmol})$ were dissolved in the mixture of $\mathrm{MeOH}(2.0 \mathrm{~mL})$ and THF $(2.0 \mathrm{~mL})$. The mixture was stirred at room temperature for $48 \mathrm{~h}$. The solvent was removed under reduced pressure, and the product was purified by column 
chromatography $\left(\mathrm{CH}_{2} \mathrm{Cl}_{2}: \mathrm{CH}_{3} \mathrm{OH}\right.$ from $60: 1$ to $\left.30: 1\right)$ to give a white powder (203.5 mg, 0.29 mmol, 57\%). ${ }^{1} \mathrm{H}$ NMR (400 MHz, $\left.\mathrm{CDCl}_{3}: \mathrm{CD}_{3} \mathrm{OD}, 1: 1\right): \delta 7.74(\mathrm{~d}, J=8.0 \mathrm{~Hz}, 2 \mathrm{H}), 7.40-7.24(\mathrm{~m}$, 12H), $5.40\left(\mathrm{CH}_{2} \mathrm{Cl}_{2}\right), 3.96(\mathrm{~s}, 1 \mathrm{H}), 3.81(\mathrm{~s}, 1 \mathrm{H}), 3.75(\mathrm{~m}, 1 \mathrm{H}), 3.65\left(\mathrm{~s}, 3 \mathrm{H}, \mathrm{OCH}_{3}\right), 2.45-1.0(\mathrm{~m}$, $26 \mathrm{H}), 0.98(\mathrm{~d}, J=8.0 \mathrm{~Hz}, 3 \mathrm{H}), 0.94(\mathrm{~s}, 3 \mathrm{H}) 0.70(\mathrm{~s}, 3 \mathrm{H}), \mathrm{NH}$ not observed; ${ }^{13} \mathrm{C}$ NMR (400 MHz, $\left.\mathrm{CDCl}_{3}: \mathrm{CD}_{3} \mathrm{OD}, 1: 1\right) \delta 175.0,167.1,141.3,141.2,135.9,135.8,134.3,133.3,133.1,132.8$ 132.6, 128.5, 128.1, 128.0, 126.6, 126.5, 72.4, 67.5, 50.8, 49.9, 46.4, 45.8, 41.6, 41.2, 38.9, 35.6, 35. 5, 35.0, 34.2, 34.2, 33.1, 30.5, 27.7, 27.0, 26.6, 26.0, 25.1, 24.4, 22.6, 21.9, 16.3, 11.7 (some aromatic carbon signals were split by the phosphorus); ${ }^{31} \mathrm{P}$ NMR (400 MHz, $\mathrm{CDCl}_{3}: \mathrm{CD}_{3} \mathrm{OD}$, 1:1): $\delta$-6.2; High resolution ACPI-MS $(m / z):[\mathrm{M}+\mathrm{H}]^{+}$calcd for $\mathrm{C}_{44} \mathrm{H}_{57} \mathrm{NO}_{5} \mathrm{P}, 710.3969$; found, 710.3979 .

4.2.3. Synthesis of Ligand 1: Compound 6 ( $200 \mathrm{mg}, 0.28 \mathrm{mmol})$ was dissolved in $\mathrm{MeOH}(10.0$ $\mathrm{mL})$ followed by addition of $\mathrm{NaOH}(1.0 \mathrm{M}, 2.82 \mathrm{~mL}, 2.8 \mathrm{mmol})$. The reaction mixture was stirred at room temperature for $12 \mathrm{~h}$ and monitored via TLC. Upon completion of the reaction, the solvent was removed under reduced pressure. The yellow solid collected was purified by column chromatography $\left(\mathrm{CH}_{2} \mathrm{Cl}_{2}: \mathrm{CH}_{3} \mathrm{OH}=20: 1\right)$ to give a white powder $(183 \mathrm{mg}, 0.26 \mathrm{mmol}$, 93\%). ${ }^{1} \mathrm{H}$ NMR (400 MHz, $\left.\mathrm{CDCl}_{3}: \mathrm{CD}_{3} \mathrm{OD}, 1: 1\right): \delta 8.04(\mathrm{~d}, J=12.0 \mathrm{~Hz}, 1 \mathrm{H}, \mathrm{NH}), 7.74(\mathrm{~d}, J=$ $8.0 \mathrm{~Hz}, 2 \mathrm{H}), 7.40-7.12(\mathrm{~m}, 12 \mathrm{H}), 3.96(\mathrm{~s}, 1 \mathrm{H}), 3.81(\mathrm{~s}, 1 \mathrm{H}), 3.76(\mathrm{~m}, 1 \mathrm{H}), 3.35\left(\mathrm{CH}_{3} \mathrm{OH}\right), 2.40-$ $1.04(\mathrm{~m}, 26 \mathrm{H}), 1.0(\mathrm{~d}, \mathrm{~J}=6.0 \mathrm{~Hz}, 3 \mathrm{H}), 0.93(\mathrm{~s}, 3 \mathrm{H}) 0.7(\mathrm{~s}, 3 \mathrm{H}), ;{ }^{13} \mathrm{C} \mathrm{NMR}(400 \mathrm{MHz}$, $\left.\mathrm{CDCl}_{3}: \mathrm{CD}_{3} \mathrm{OD}, 1: 1\right): \delta 176.4,166.9,141.2,141.1,135.8,135.6,134.1,133.1,132.9,132.6$ 132.4, 128.3, 127.9, 127.8, 126.43, 126.36, 72.1, 67.2, 49. 8, 46.2, 45.6, 41.5, 41.1, 38.8, 35.3, $34.8,34.0,33.9,32.9,30.4,27.6,26.9,26.4,25.9,24.9,24.2,22.4,21.8,16.2,11.6$ (some aromatic carbon signals were split by the phosphorus); ${ }^{31} \mathrm{P} \mathrm{NMR}\left(400 \mathrm{MHz}, \mathrm{CDCl}_{3}: \mathrm{CD}_{3} \mathrm{OD}\right.$, 
1:1): $\delta$-5.0; High resolution ESI-MS (m/z): $[\mathrm{M}-\mathrm{H}]^{-}$calcd for $\mathrm{C}_{43} \mathrm{H}_{53} \mathrm{NO}_{5} \mathrm{P}, 694.3656$; found, 694.3649.

4.3. General procedure for in situ Heck reaction: To a $20-\mathrm{mL}$ vial, $5 \times 10^{-3} \mathrm{mmol}$ of $\mathrm{PdCl}_{2}\left(\mathrm{CH}_{3} \mathrm{CN}\right)_{2}$ or $\mathrm{Pd}(\mathrm{OAc})_{2}$ and $15 \times 10^{-3} \mathrm{mmol}$ of 1 were added, followed by $0.24 \mathrm{mmol} 4-$ iodoanisole, $0.48 \mathrm{mmol} t$-Bu-acrylate, $0.72 \mathrm{mmol} \mathrm{NEt}_{3}$, and $2.0 \mathrm{~mL} \mathrm{H} \mathrm{H}_{2} \mathrm{O}$. The reaction mixturewas ultrasonicated for $10 \mathrm{~min}$ and then stirred at $40{ }^{\circ} \mathrm{C}$ for $18 \mathrm{~h}$. At the completion of the reaction, all volatiles were removedunder vacuum, and 50. $\mu \mathrm{L}$ of an internal standard (10. mMmesitylene in $\left.\mathrm{CDCl}_{3}\right)$ was added to the vial. The reaction was then extracted with $\mathrm{CDCl}_{3}(3$ $\times 200 . \mu \mathrm{L}$ ). All organic extracts were combined and passed through a plug of celite and $\mathrm{MgSO}_{4}$ into an NMR tube. Yieldswere determined by ${ }^{1} \mathrm{H}$ NMR spectroscopy by integration of the protons of the cinnamate product, using mesitylene as the internal standard.In general, both the aromatic and the methyl protons were used in the calculation and the results were averaged to give the reported NMR yields.

4.4. Coordination of 1 with $\mathrm{Pd}(\mathrm{OAc})_{2}$ : $\mathrm{Pd}(\mathrm{OAc})_{2}\left(5.4 \mathrm{mg}, 2.4 \times 10^{-2} \mathrm{mmol}\right)$ and 1 (50. $\mathrm{mg}, 7.2$ $\left.\times 10^{-2} \mathrm{mmol}\right)$ were combined in $\mathrm{MeOH}(10 \mathrm{~mL})$ and treated by sonication at $25{ }^{\circ} \mathrm{C}$ for $30 \mathrm{~min}$, resulting in a hazy, yellow solution. Into $20-\mathrm{mL}$ glass vials, $1.0 \mathrm{~mL}$ of this solution was delivered and all volatiles were removed under vacuum, leaving a dry, yellow residue to be directly used for catalysis.

4.5. General procedure for Heck reaction with ligand-Pd precoordination: To the dry, yellow catalyst residue, aryl iodide $(0.12 \mathrm{mmol})$, acrylate $(0.24 \mathrm{mmol}), 1.0 \mathrm{~mL} \mathrm{H}_{2} \mathrm{O}$, and $\operatorname{NEt}_{3}(51 \mu \mathrm{L}, 0.36 \mathrm{mmol})$ were added to the vial in the specified order. The reaction was thoroughly mixed via sonication for $10 \mathrm{~min}$ and subsequently stirred for the indicated time and temperature. At the completion of the reaction, all volatiles were removed under vacuum, and 
50. $\mu \mathrm{L}$ of internal standard (10. $\mathrm{mMmesitylene}$ in $\left.\mathrm{CDCl}_{3}\right)$ was added to the vial. The reaction was then extracted with $\mathrm{CDCl}_{3}(3 \times 200 . \mu \mathrm{L})$. All organic extracts were combined and passed through a plug of celite and $\mathrm{MgSO}_{4}$ into an NMR tube. Yields were determined by ${ }^{1} \mathrm{H}$ NMR spectroscopy.

\subsection{GeneralProcedure for Scaled-Up Heck Reaction with Ligand-Pd Precoordination:}

$\mathrm{Pd}(\mathrm{OAc})_{2}\left(5.4 \mathrm{mg}, 2.4 \times 10^{-2} \mathrm{mmol}\right)$ and $\mathbf{1}\left(50 . \mathrm{mg}, 7.2 \times 10^{-2} \mathrm{mmol}\right)$ were combined in $\mathrm{MeOH}$ (10. $\mathrm{mL}$ ) and treated by sonication at $25{ }^{\circ} \mathrm{C}$ for $30 \mathrm{~min}$, resulting in a hazy, yellow solution. Into 20-mL glass vials, $5.0 \mathrm{~mL}$ of this solution was delivered and all volatiles were removed under vacuum, leaving a dry, yellow residue to be used directly for catalysis. To the dry, yellow catalyst residue, aryl iodide $(0.60 \mathrm{mmol})$, acrylate $(1.2 \mathrm{mmol}), 5.0 \mathrm{~mL} \mathrm{H}_{2} \mathrm{O}$, and $\mathrm{NEt}_{3}(250 \mu \mathrm{L}$, $1.8 \mathrm{mmol}$ ) were added to the vial in the specified order. The reaction was thoroughly mixed via sonication for $10 \mathrm{~min}$ and subsequently stirred for $12 \mathrm{~h}$ at $40{ }^{\circ} \mathrm{C}$. At the completion of the reaction, all volatiles were removed under vacuum, and the remaining aqueous solution was extracted with ethyl acrylate $(3 \times 5 \mathrm{~mL})$. The ethyl acrylate extracts were combined, dried with $\mathrm{MgSO}_{4}$, and all volatiles were removed under vacuum. The resulting crude was purified via column chromatography.

Methyl (E)-3-(4-methoxyphenyl)acrylate. Clear Oil, $76 \mathrm{mg}, 0.40 \mathrm{mmol}, 65 \% ;{ }^{1} \mathrm{H}$ NMR (400 $\left.\mathrm{MHz}, \mathrm{CDCl}_{3}\right) \delta(\mathrm{ppm}): 7.66(\mathrm{~d}, J=16.0 \mathrm{~Hz}, 1 \mathrm{H}), 7.48(\mathrm{~d}, J=8.4 \mathrm{~Hz}, 2 \mathrm{H}), 6.91(\mathrm{~d}, J=8.4 \mathrm{~Hz}$, 2H), $6.32(\mathrm{~d}, J=16.0 \mathrm{~Hz}, 1 \mathrm{H}), 3.85(\mathrm{~s}, 3 \mathrm{H}), 3.80(\mathrm{~s}, 3 \mathrm{H})$.

Ethyl (E)-3-(4-methoxyphenyl)acrylate. Clear Oil, $106 \mathrm{mg}, 0.51 \mathrm{mmol}, 86 \%$; ${ }^{1} \mathrm{H}$ NMR (400 $\left.\mathrm{MHz}, \mathrm{CDCl}_{3}\right) \delta(\mathrm{ppm}): 7.65(\mathrm{~d}, J=15.6 \mathrm{~Hz}, 1 \mathrm{H}), 7.48(\mathrm{~d}, J=8.8 \mathrm{~Hz}, 2 \mathrm{H}), 6.91(\mathrm{~d}, J=8.8 \mathrm{~Hz}$, 2H), $6.32(\mathrm{~d}, J=16.0 \mathrm{~Hz}, 1 \mathrm{H}), 4.27(\mathrm{q}, J=7.2 \mathrm{~Hz}, 2 \mathrm{H}), 3.85(\mathrm{~s}, 3 \mathrm{H}), 1.34(\mathrm{t}, J=7.2 \mathrm{~Hz}, 3 \mathrm{H})$. 
Butyl (E)-3-(4-methoxyphenyl)acrylate. Clear Oil, $134 \mathrm{mg}, 0.57 \mathrm{mmol}, 95 \% ;{ }^{1} \mathrm{H}$ NMR (400 $\left.\mathrm{MHz}, \mathrm{CDCl}_{3}\right) \delta(\mathrm{ppm}): 7.65(\mathrm{~d}, J=16.0 \mathrm{~Hz}, 1 \mathrm{H}), 7.48(\mathrm{~d}, J=8.8 \mathrm{~Hz}, 2 \mathrm{H}), 6.91(\mathrm{~d}, J=8.8 \mathrm{~Hz}$ 2H), $6.32(\mathrm{~d}, J=16.0 \mathrm{~Hz}, 1 \mathrm{H}), 4.20(\mathrm{t}, J=6.8 \mathrm{~Hz}, 2 \mathrm{H}), 3.84(\mathrm{~s}, 3 \mathrm{H}), 1.69(\mathrm{~m}, 2 \mathrm{H}), 1.45(\mathrm{~m}, 2 \mathrm{H})$, $0.97(\mathrm{t}, J=7.2 \mathrm{~Hz}, 3 \mathrm{H})$.

2-Ethylhexyl (E)-3-(4-methoxyphenyl)acrylate. White Solid, $162 \mathrm{mg}, 0.56 \mathrm{mmol}, 93 \% ;{ }^{1} \mathrm{H}$ NMR (400 MHz, $\left.\mathrm{CDCl}_{3}\right) \delta(\mathrm{ppm}): 7.65(\mathrm{~d}, J=16.0 \mathrm{~Hz}, 1 \mathrm{H}), 7.49(\mathrm{~d}, J=8.8 \mathrm{~Hz}, 2 \mathrm{H}), 6.91(\mathrm{~d}$, $J=8.8 \mathrm{~Hz}, 2 \mathrm{H}), 6.32(\mathrm{~d}, J=16.0 \mathrm{~Hz}, 1 \mathrm{H}), 4.12(\mathrm{~m}, 2 \mathrm{H}), 3.85(\mathrm{~s}, 3 \mathrm{H}), 1.65(\mathrm{~m}, 1 \mathrm{H}), 1.48-1.27$ (m, 8H), 0.96-0.90 (m, 6H).

tert-Butyl (E)-3-(4-methoxyphenyl)acrylate. White Solid, $136 \mathrm{mg}, 0.58 \mathrm{mmol}, 96 \% ;{ }^{1} \mathrm{H}$ NMR $\left(400 \mathrm{MHz}, \mathrm{CDCl}_{3}\right) \delta(\mathrm{ppm}): 7.55(\mathrm{~d}, J=16.0 \mathrm{~Hz}, 1 \mathrm{H}), 7.46(\mathrm{~d}, J=8.8 \mathrm{~Hz}, 2 \mathrm{H}), 6.89(\mathrm{~d}, J=8.8$ $\mathrm{Hz}, 2 \mathrm{H}), 6.24(\mathrm{~d}, J=16.0 \mathrm{~Hz}, 1 \mathrm{H}), 3.85$ (s, 3H), 1.54 (s, 9H).

tert-Butyl (E)-3-(p-tolyl)acrylate. White Solid, $123 \mathrm{mg}, 0.56 \mathrm{mmol}, 94 \% ;{ }^{1} \mathrm{H}$ NMR (400 MHz, $\left.\mathrm{CDCl}_{3}\right) \delta(\mathrm{ppm}): 7.57(\mathrm{~d}, J=16.0 \mathrm{~Hz}, 1 \mathrm{H}), 7.41(\mathrm{~d}, J=8.0 \mathrm{~Hz}, 2 \mathrm{H}), 7.18(\mathrm{~d}, J=8.0 \mathrm{~Hz}, 2 \mathrm{H})$, $6.33(\mathrm{~d}, J=16.0 \mathrm{~Hz}, 1 \mathrm{H}), 2.38(\mathrm{~s}, 3 \mathrm{H}), 1.54(\mathrm{~s}, 9 \mathrm{H})$.

tert-Butyl (E)-3-(naphthalen-1-yl)acrylate. White Solid, $139 \mathrm{mg}, 0.55 \mathrm{mmol}, 91 \% ;{ }^{1} \mathrm{H}$ NMR $\left(400 \mathrm{MHz}, \mathrm{CDCl}_{3}\right) \delta(\mathrm{ppm}): 8.45(\mathrm{~d}, J=15.6 \mathrm{~Hz}, 1 \mathrm{H}), 8.21(\mathrm{~d}, J=8.4 \mathrm{~Hz}, 1 \mathrm{H}), 7.88(\mathrm{~d}, J=8.4$ $\mathrm{Hz}, 2 \mathrm{H}), 7.75(\mathrm{~d}, J=7.2,1 \mathrm{H}), 7.62-7.42(\mathrm{~m}, 3 \mathrm{H}), 6.47(\mathrm{~d}, J=15.6 \mathrm{~Hz}, 1 \mathrm{H}), 1.60(\mathrm{~s}, 9 \mathrm{H})$.

(E)-1-Methoxy-4-styrylbenzene. White Solid, $103 \mathrm{mg}, 0.49 \mathrm{mmol}, 82 \%$; ${ }^{1} \mathrm{H}$ NMR $(400 \mathrm{MHz}$, $\left.\mathrm{CDCl}_{3}\right) \delta(\mathrm{ppm}): 7.50(\mathrm{~d}, J=7.2 \mathrm{~Hz}, 2 \mathrm{H}), 7.47(\mathrm{~d}, J=8.4 \mathrm{~Hz}, 2 \mathrm{H}), 7.36(\mathrm{t}, J=7.2 \mathrm{~Hz}, 2 \mathrm{H}), 7.24$ $(\mathrm{t}, J=7.2 \mathrm{~Hz}, 1 \mathrm{H}), 7.08(\mathrm{~d}, J=16.4 \mathrm{~Hz}, 1 \mathrm{H}), 7.02(\mathrm{~d}, J=16.4 \mathrm{~Hz}, 1 \mathrm{H}), 6.91(\mathrm{~d}, J=8.4 \mathrm{~Hz}, 2 \mathrm{H})$, $3.85(\mathrm{~s}, 3 \mathrm{H})$.

(E)-1-Methoxy-4-(4-methylstyryl)benzene. White Solid, $108 \mathrm{mg}, 0.48 \mathrm{mmol}, 80 \%$; ${ }^{1} \mathrm{H}$ NMR $\left(400 \mathrm{MHz}, \mathrm{CDCl}_{3}\right) \delta(\mathrm{ppm}): 7.45(\mathrm{~d}, J=8.4 \mathrm{~Hz}, 2 \mathrm{H}), 7.39(\mathrm{~d}, J=8.0 \mathrm{~Hz}, 2 \mathrm{H}), 7.16(\mathrm{~d}, J=8.4$ 
$\mathrm{Hz}, 2 \mathrm{H}), 7.03(\mathrm{~d}, J=16.0 \mathrm{~Hz}, 1 \mathrm{H}), 7.00(\mathrm{~d}, J=16.0 \mathrm{~Hz}, 1 \mathrm{H}), 6.91(\mathrm{~d}, J=8.4 \mathrm{~Hz}, 2 \mathrm{H}), 3.84(\mathrm{~s}$, $3 \mathrm{H}), 2.37(\mathrm{~s}, 3 \mathrm{H})$.

4.7. General procedure for heterogeneity tests: To dry, yellow catalyst residue, iodoanisole (0.12 mmol), $t$-Bu-acrylate $(0.24 \mathrm{mmol}), 1.0 \mathrm{~mL} \mathrm{H}_{2} \mathrm{O}$, and $\mathrm{NEt}_{3}(51 \mu \mathrm{L}, 0.36 \mathrm{mmol})$ were added to the vial in the specified order. The reaction was thoroughly mixed via sonication for $10 \mathrm{~min}$ and subsequently stirred at $40{ }^{\circ} \mathrm{C}$. At $2 \mathrm{~h}$, the reaction mixture was centrifuged at $18{ }^{\circ} \mathrm{C}$ and 16,200 $\mathrm{g}$ for $30 \mathrm{~min}$. The two fractions were separated and the solid fraction was reconstituted with more iodoanisole $(0.12 \mathrm{mmol}), t$-Bu-acrylate $(0.24 \mathrm{mmol}), \mathrm{H}_{2} \mathrm{O}(1.0 \mathrm{~mL})$, and $\mathrm{NEt}_{3}(51 \mu \mathrm{L}$, $0.36 \mathrm{mmol})$. The reconstituted solid fraction was stirred at $40{ }^{\circ} \mathrm{C}$ for an additional $2 \mathrm{~h}$. To the supernatant fraction, more iodoanisole $(0.12 \mathrm{mmol}), t$-Bu-acrylate $(0.24 \mathrm{mmol})$, and $\mathrm{NEt}_{3}(51 \mu \mathrm{L}$, $0.36 \mathrm{mmol}$ ) were added. The reconstituted supernatant fraction was stirred at $40{ }^{\circ} \mathrm{C}$ for an additional $6 \mathrm{~h}$. Product workup and analysis wereaccomplished as described above. This procedure was performed in triplicate. The overall average yield of cinnamate product from the solid fractions was $96 \%$, whereas the supernatant fractions never provided more than a trace amount of product via NMR.

\section{Acknowledgments}

We thank the U.S. Department of Energy (award DESC0002142) and NSF (CHE-0809901 and EEC-0813570: ERC Center for Biorenewable Chemicals, CBiRC, at Iowa State University)for partial support of this work.

\section{Supplementary Data}

Supplementary Data available: Synthetic procedures for the syntheses of compounds 3 and $\mathbf{4}$; NMR spectra for Heck products, cholate phosphine ester $\mathbf{6}$, and cholate phosphine ligand $\mathbf{1}$.

\section{References}


(1) Cornils, B.; Herrmann, W. A. Aqueous-Phase Organometallic Catalysis: Concepts and Applications; 2nd ed.; Wiley-VCH: Weinheim, 2004.

(2) Shaughnessy, K. H. Chem. Rev.2009, 109, 643-710.

(3) Li, C.-J. Chem. Rev.2005, 105, 3095-3166.

(4) Lindström, U. M. Chem. Rev.2002, 102, 2751-2772.

(5) Menger, F. M.; Gan, L. H.; Johnson, E.; Durst, D. H. J. Amer. Chem. Soc.1987, 109, 28002803.

(6) Dwars, T.; Paetzold, E.; Oehme, G. Angew. Chemie Intl. Ed.2005, 44, 7174-7199.

(7) Lipshutz, B. H.; Ghorai, S. Aldrichim. Acta2008, 41, 59-72.

(8) Danielsson, H.; Sjövall, J. Sterols and Bile Acids; Elsevier: Amsterdam, 1985.

(9) Zhao, Y. Curr. Opin. Colloid In. Sci.2007, 12, 92-97.

(10) Brotherhood, P. R.; Davis, A. P.Chem. Soc. Rev. 2010, 39, 3633-3647.

(11) Li, Y.; Dias, J. R. Chem. rev.1997, 97, 283-304.

(12) Virtanen, E.; Kolehmainen, E. Eur. J. Org. Chem.2004, 2004, 3385-3399.

(13) (a) Zhao, Y.; Cho, H.; Widanapathirana, L.; Zhang, S. Acc. Chem. Res.2013, 46, 27632772. (b) Zhao, Y.; Zhong, Z.; Ryu, E.-H. J. Am. Chem. Soc.2007, 129, 218-225. (c) Cho, H.; Zhong, Z.; Zhao, Y. Tetrahedron2009, 65, 7311-7316. (d) Cho, H.; Zhao, Y. J. Am. Chem. Soc.2010, 132, 9890-9899. (e) Cho, H.; Widanapathirana, L.; Zhao, Y. J. Am. Chem. Soc.2011, 133, 141-147. (f) Zhong, Z.; Li, X.; Zhao, Y. J. Am. Chem. Soc.2011, 133, 8862-8865. (g) Gunasekara, R. W.; Zhao, Y. J. Am. Chem. Soc.2015, 137, 843-849.

(14) Small, D. M. In Molecular Association in Biological and Related Systems; Goddard, E., Ed.; Advances in Chemistry; American Chemical Society: Washington, DC, 1968; Vol. 84, pp. 31-52. 
(15) Sugioka, H.; Moroi, Y. BBA-Lipid. Lipid Met.1998, 1394, 99-110.

(16) Ju, C.; Bohne, C. J. Phys. Chem.1996, 100, 3847-3854.

(17) O'Connor, C. J. Wallace, R. G. Adv. Colloid Interface Sci.1985, 22, 1-111.

(18) Small, D. M. In The bile acids; chemistry, physiology, and metabolism; Nair, P. P.; Kritchevsky, D.; Setchell, K. D. R. Eds.; Plenum Press: New York, 1971; pp. 249-356.

(19) Blickenstaff, R. T.; Orwig, B. J. Org. Chem.1969, 34, 1377-1381.

(20) Wolf, G. C.; Foster, E. L.; Blickenstaff, R. T. J. Org. Chem. 1973, 38, 1276-1279.

(21) Fieser, L. F.; Rajagopalan, S. J. Am. Chem. Soc.1950, 72, 5530-5536.

(22) Davis, A. P.; Dresen, S.; Lawless, L. J. Tetrahedron Lett.1997, 38, 4305-4308.

(23) Rentsch, D.; Hany, R.; Barthélémy, S.; Steinauer, R. Tetrahedron Lett.2003, 44, 69876990.

(24) Oakenfull, D. G.; Fisher, L. R. J. Phys. Chem.1977, 81, 1838-1841.

(25) Amatore, C.; Carre, E.; Jutand, A.; M’Barki, M. A.; Meyer, G. Organometallics1995, 14, $5605-5614$.

(26) Amatore, C.; Jutand, A.; M’Barki, M. A. Organometallics1992, 11, 3009-3013.

(27) Amatore, C.; Carre, E.; Jutand, A.; M'Barki, M. A. Organometallics1995, 14, 1818-1826.

(28) Csákai, Z.; Skoda-Foldes, R.; Kollár, L. Inorg. Chim. Acta1999, 286, 93-97.

(29) In the presence of $\mathrm{NEt}_{3}$, heat and water, the catalyst visibly formed palladium black within $24 \mathrm{~h}$ and fully decomposed within $48 \mathrm{~h}$.

(30) For two reviews, see: (a) M. Miyata, K. Sada, in: J. L. Atwood, J. E. D. Davis, D. D. MacNicol, F. Vögtle (Eds.), Comprehensive Supramolecular Chemistry, Elsevier, Oxford, 1996, Vol. 6, Chapter 6. (b) M. Miyata, K. Sada, N. Yoswathananont, in: J. L. 
Atwood, J. W. Steed (Eds.), Encyclopedia of Supramolecular Chemistry, Marcel Dekker, New York, p 441.

(31) Beletskaya, I. P.; Cheprakov, A. V. Chem. Rev.2000, 100, 3009-3066.

(32) DeVasher, R. B.; Moore, L. R.; Shaughnessy, K. H. J. Org. Chem.2004, 69, 7919-7927.

(33) Moore, L. R.; Shaughnessy, K. H. Org. Lett.2004, 6, 225-228.

(34) Jagtap, S.; Deshpande, R. Tetrahedron Lett.2013, 54, 2733-2736.

(35) Bistri, 0.; Reinaud, O. Org. Biomol. Chem. 2015, 13, 2849-2865.

(36) Senra, J. D.; Malta, L. F. B.; Souza, A. L. F.; Aguiar, L. C. S.; Antunes, O. A. C. Adv. Synth. Catal.2008, 350, 2551-2558.

(37) Zhao, Y.; Zhong, Z. J. Amer. Chem. Soc.2005, 127, 17894-17901. 


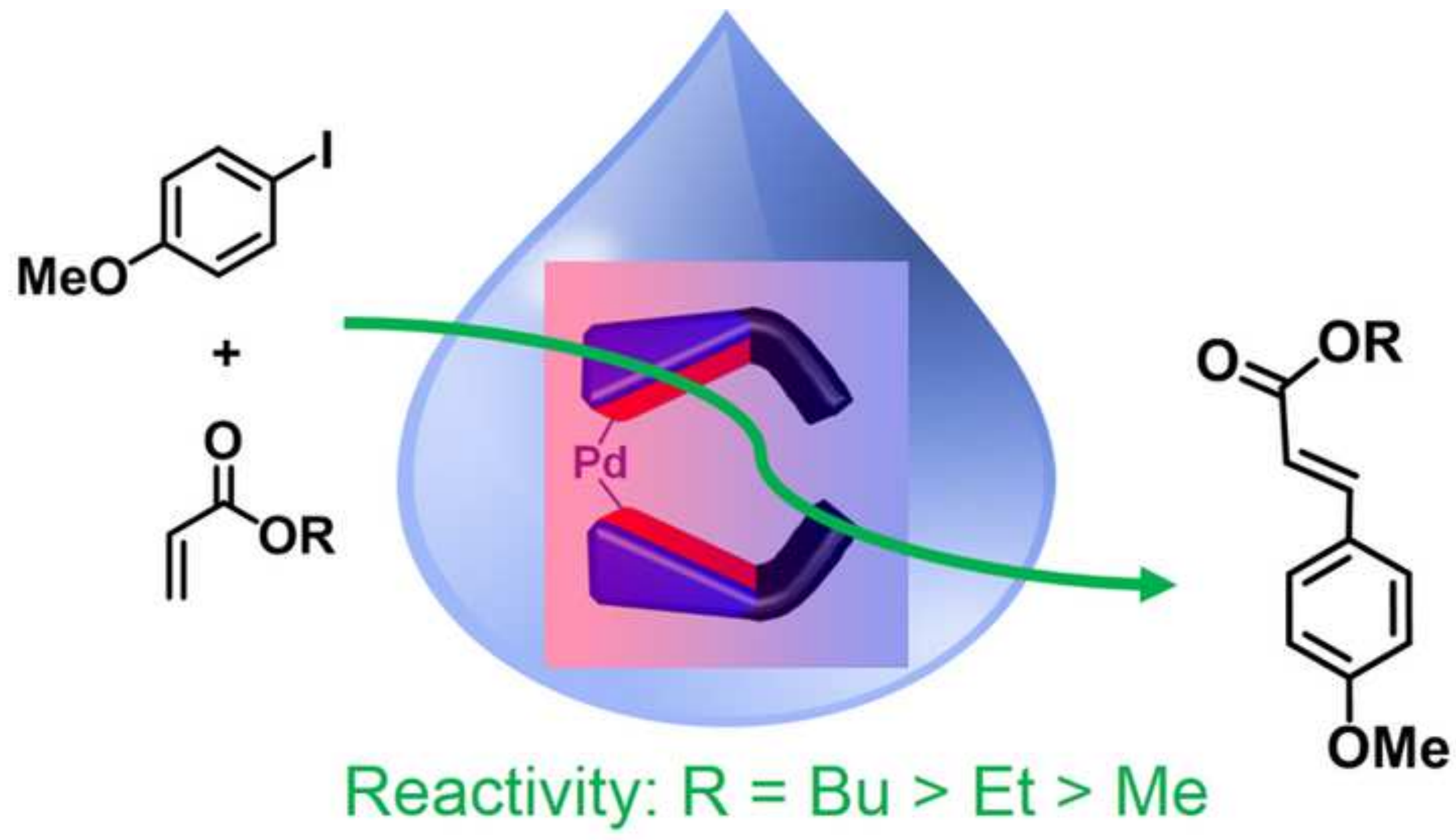

